\title{
ARTICLES \\ The Structure and Function of Funeral Rituals and Customs in Ukraine Natalia Havryl'iuk
}

Institute of Ethnomusicology, Folklore and Ethnography of the Ukrainian Academy of Sciences

Traditional funeral rituals and customs in Ukraine reflect a complex system of religious and magic beliefs. Psychological considerations play an important role, as does the desire to behave in a proper and moral fashion. Thus, Ukrainian funerals exhibit a combination of efforts on behalf of the deceased and actions intended to relieve the emotional and psychological tension of the living. Symbolic acts, such as the need to honor a deceased family or community member, are combined with very practical behaviors, those based on considerations of hygiene. In essence, in funerals we see ancient, pre-Christian beliefs in the interrelatedness of the living and the dead, beliefs that the connection between this world and the world beyond the grave is real and permanent, and that ancestors must be honored and remembered into eternity. Folk beliefs of ancient origin have, of course, now been combined with the Christian outlook on life after death and a layer of Orthodox Christianity superimposed on the folk stratum.

Ukrainian funerary rituals have a distinct structure composed of the following components: omens foretelling death, the death itself, the funeral, the burial, and the wake. Neither the Ukrainian funeral ritual as a whole nor its various components have been the subject of any significant and sustained research. This fact was noted by several scholars at the beginning of the 20th century [Kuzelia 1912: 136, 165-66]. There were individual studies, notably Kuzelia's own and the contemporaneous work by Hnat'iuk [1912], but there was little follow-up on the publications of the early twentieth century during the Soviet period. Thus, while field data was systematically gathered for birth customs and wedding rites [Shubravs'ka and Pravdiuk 1970; Havryl'iuk 1981], funerary ritual was neglected. In the West little attention has been paid to Ukrainian funerals, and what has appeared is based on written sources [Worobec 1994]. Because there has not been a great deal of systematic attention to the Ukrainian funeral, this article does not claim to be a definitive treatment. Rather, it seeks to be a first step toward filling the gap in our knowledge of Ukrainian funerary customs and beliefs. It attempts to be a synthesis of previously published data, much of it from the late nineteenth century and the beginning of the twentieth [Hnat'iuk 1912; Shukhevych 1902; Iaschurzhinskii 1893], data published more recently [Ivanov, Nevskaia 1990; Surkhasko 1985; Gracheva 1983] and the author's own field work, some of it published, [Havryl'iuk 1985a, 1985b], but much of it available only in archival form. Data on Ukrainian funerals was collected by the author in the 1980s and the 1990s in the villages of the Polissia, Dnieper, Transcarpathia, and Podillia regions. It is housed in her private archive.

\section{Beliefs And Rituals Related To Death And Preparation For Burial}

An integral part of the folk worldview is the belief that death is always presaged by omens (pryznaky na smert', na vmerushche). Typical omens include unusual behavior on the part of animals, birds, or insects. If household utensils are found arranged in a certain way, this can be seen as an indication that death will soon 
visit the home in question. Certain sounds and tactile sensations are said to be portents of death, as are certain types of dreams. For example, an omen that indicates that a family member, usually the male head of the household, is about to die is the howling of a dog, especially at the feet of the person in question (pes vyie na lapy). A dog digging at the earth near the house foreshadows death, as does a cow escaping into a neighbor's yard. Other omens include a shrew continuously digging dirt in the yard (krit krute) or a toad finding its way into the house proper. Insect omens include the ceaseless chirping of house crickets and the sudden appearance of a great number of houseflies or bees.

Certain signs are deemed to bode ill in general, but, when there is a sick or an elderly individual in the household, the evil omen can be considered a portent of death. Such bad signs include imaginary tapping (a tapping sound with no apparent source), strange noises in the attic, the unexplained falling and especially breaking of household utensils or icons, and the unexplained creaking of a table or a door. Of these, an icon falling is probably the most feared omen.

Nocturnal birds of prey, such the various species of owl common in Ukraine, are among the best-known messengers of death. According to folk legends, when death is near, owls have a special death-heralding call. They perform this call while sitting on a chimney, a tree, or another tall object in the yard of the house where a death will occur. The call sounds like: "pokhovav-pokhovav" which means "someone has been buried" in Ukrainian. The hoopoe also has a cry that sounds like Ukrainian. It goes "khudo-tut, khudo-tut" (trouble's here) and this, too is considered a bad omen meaning that death is near. Other bird omens include a turtle dove making a peculiar cry that sounds like the call of an owl, a blue tit hitting a window pane, a sparrow fluttering at the window in the afternoon, and a cuckoo flying into the yard. Another negative sign is hearing knocking or calls in a yard empty of people or animals, whereas an itching on one's nose, either at the bridge or at the tip, is said to indicate that there would soon be a dead person in the household (na mertsia).

Many dreams are believed to herald trouble. In one of the most common of such dreams, a person known to be dead calls the living, asking the dreamer to join the deceased. Should the dreamer accept the invitation, this is considered a particularly bad omen. Dreaming of the following items is perceived as an indication that the funeral of a family member is immanent: an icon, a bloody lost tooth, the collapse of a part of the home, such as the chimney, roof, or wall, gates knocked off their hinges, smoke blowing from the gate into the house, a piece of smoldering coal in the oven, a bird flying away from the yard, a herd of cattle, a flock of sheep or a hen with her young, the theft of a pig or horse, attempts to drive away large houseflies. Dreaming of all of these items can also indicate that a death has already occurred, only the dreamer is not aware that someone close to him or her has died. This would be the case if the deceased is a family member living apart from the dreamer.

Dreams foretelling death can also contain the following: a ploughed field or vegetable garden, the dreamer herself digging or turning garden beds, strewn manure, or dry grass. Dreaming about a living tree, especially an apple tree in bloom, being uprooted is bad and even more so if the tree is uprooted by an old man whom the dreamer knows to be deceased. Dreaming about certain vegetables can be a portent of death and the vegetables include cabbage, potatoes, and ripe watermelons. Dreams about certain actions are bad omens, 
signifying that one's own death is near; these include dreams about felling trees, gathering firewood, and looking into a well. Certain dreams indicate where the next death in a village will occur, specifically dreams of a rising flood and a certain point on the shore toward which a boat is moving. If the dreamer sees a wedding party and that wedding party bypasses a house, then that house will be the place where a death will soon occur.

\section{Preparing For Death}

Preparing for death is considered extremely important. A central folk belief, supported by Orthodox Christianity, holds that existence on earth is but a transient state. According to this belief, "we are guests" in this world and "live in sin," whereas our permanent abode is in the world beyond. One informant stated: "We said goodbye [to the dying], and he is now in the place of truth, while we remain but guests here, living in sin."(1) With such a worldview, it is considered extremely important to follow the steps traditionally believed to ensure or simplify one's passage to the other world.

One important item is the clothing that will be used for the deceased. This is made ready well in advance. Clothing can either be specially bought for the occasion or, as was more common in earlier times, festive or wedding clothes can be washed, prepared, and set aside to be used for the funeral. According to at least one report, any clothing is acceptable, even used clothing, as long as it is clean. According to a folk saying, the belief is that "death will find a shirt (for itself)."(2)

Imminent death creates an atmosphere of concentrated attention around the dying person. In the room, actions are executed quietly and conversations are subdued, for it is believed that a silence broken makes dying more difficult. According to one informant, "Shouting interrupts death, and [the dying person] will suffer more.”(3) In order to ease the agony of death, a dying person can be laid out on the ground. Making a hole in the roof is also thought to help ease a prolonged death agony. This is done mainly for people deemed to be wizards and witches, since their "demonic affiliation" reportedly makes their death especially protracted and painful.

In order to enable a dying person to clearly recollect all of his or her sins and thus to confess them, he or she is given a candle (hromnytsia), that has been blessed on the day of the Meeting of the Lord (Jan 19/Feb. 6). Holding the candle is also said to illuminate the future path of the soul [Kravchenko 1920: 106]. The dying are supposed to ask God, their relatives and friends for forgiveness, repeating the request three times: "Dear Lord, forgive me my sins, the first time, the second time and the third time." A typical dialogue goes as follows: "Forgive me if I ever said or did anything wrong", says the dying person, to which each of those present replies: "God will forgive, and I forgive." Forgiveness is supposed to be mutual and those who arrive too late to ask for forgiveness while a person is still alive, make their request of the dead body. While a person is dying, his calling, in a state of delirium, persons known to be deceased, especially his own parents, is considered a certain sign of imminent death. Under such circumstances, the dying person is thought to be so close to the edge of this world as to be able to see into the next and to speak with the dead. 
Actual death and the ensuing preparation of the body for the burial triggers a set of customs and rituals based on beliefs about what happened to the body and the soul in the first hours and days after death. To a large extent, these are mystic religious acts of a purifying, protective and sacrificial nature.

The bereaved are not allowed to weep in the house before death actually comes, but, when it does, it is the loud lamentation in the yard of one of the deceased's relatives that announces to the village what has happened. In addition, church bells are rung to mark a death. The ringing of church bells later marks each of the different stages of the funeral. It is commonly believed that the corpse cannot be left alone or in the dark once the church bells have rung. The reason given is that the soul, which has left the body, stands beside it, near the head and may be captured by evil spirits. In the mountain villages of the Carpathians, a death is announced by drawn-out sounds of the trembitas (long horns). Open gates, with kerchiefs and embroidered towels tied on them, are also a way of informing the rest of the village that a death has occurred at a particular household.

One of the most widespread beliefs is that the deceased's body cannot be bathed and dressed by the members of his household. Doing so washes away connections between them and might prevent their future meeting in heaven. Thus, two or three elderly neighbors, usually those living alone and having considerable experience with the practice of preparing the dead, are asked to perform the task. The customs of the western regions of Ukraine dictate that the body be bathed by the persons of the same sex, whereas in the rest of the country women tend to do the bathing for both sexes. In certain areas of Polissia it is customary to ask the village midwife to prepare the body of the deceased, probably an ancient custom indicating parallels between entry into this world and departure from it.

The water used to bathe the body, commonly called either "dead water" (mertva voda) or "water from the deceased" (voda z mertsia), is variably ascribed harmful and healing properties and is used accordingly. In particular, it is widely believed that no man or animal should come in contact with the ground where this water has been discarded. Therefore, it is thrown out in a remote place, one where no one will tread, such as a corner of the garden or the yard, right next to the fence, near a barn, or onto manure. In the Carpathian region, it is common to pour the water away outside the boundaries of one's property, for example on the road or by a river. In these regions, the water is also used to exterminate domestic insect pests, such as cockroaches and fleas, and as a magic tool for casting spells. Those experienced in folk medicine use it for healing, treating such conditions as eye diseases and a condition called "dead bone," meaning a hard lump like a calcification somewhere on the body. The clothes and bedclothes that had been used by the deceased are most commonly burned, and the ashes are discarded in the same place as the water used for bathing the body.

The burial clothes are chosen according to the deceased's age and social status. As a measure of protection, a multicolored silk belt is usually fastened over the shirt. For an older person, the belt is usually black and white and for a younger person it is green or red. A man's head is covered with a hat, whereas women wear kerchiefs (kaptur, khustka, namitka). In keeping with an old custom, each foot of the deceased is wrapped in a white cloth (in Polissia, a kerchief or namitka is used instead) and then shod in light, soft footwear, such as straw or canvas shoes. The reason given for this practice is the fact that, in the world beyond the grave, the dead have to walk long distances. If the deceased's fingernails and toenails are trimmed during bathing, the 
clippings are hidden inside his shirt. According to folk belief, the deceased can then use them on Judgment Day if he or she needs to build a bridge to cross a river. In the areas of Podillia along the Dniester River, it is commonly believed that everyone must have a mate in the other world, and both married and single dead receive a wax ring made from the candle that had illuminated their passing away. Young unmarried people are dressed as if for their weddings and wear periwinkle, sweet basil (vasyl'ok) or artificial flower wreaths. The hair of unmarried girls who died is left loose and decorated with ribbons, as it would be for their wedding. A larger wreath, similar to the one placed on the head, is placed over the body and later hung on the grave cross.

Bathed and dressed, the body is laid out on a bench beneath the icons. The head of the deceased is supposed to be pointed towards the icon corner of the room and the feet towards the door. In the western regions, two benches placed side-by-side (katafeliok) are used instead of the bench built into the wall, characteristic of Central and Eastern region. Hutsuls, on the other hand, use a plank bed (tabla), which is often placed in the middle of the main room (khata). Children up to seven years of age are considered angels and, should they die, their bodies are always dressed up in festive clothes and laid out on a table.

The bed on which the deceased lay is made of hay, straw or conifer branches, covered with white sheets. Two towels, lain crosswise with their ends turned up over the body, are also typically used. A candle, a cross, and some money are placed in the hands of the deceased. In accordance with another custom, a towel is placed under a man's arms, whereas the hands of a woman are wrapped in a towel or covered with a handkerchief.

Lest the deceased "chose a living person to take away with him" a coin is placed on each of his eyelids to make sure that his eyes stay shut. His chin is tied up with a kerchief or cloth to keep the mouth closed and a copper coin is placed on the mouth. All of the coins used for the deceased are later buried together with the body and are supposed to give the dead person the means to pay for crossing into the other world. A needle called a "tsyhanka" is put on the lips of those who died suddenly (syra liudyna). The arms and legs of the dead are tightly secured with ropes or cords. These, however, have to be undone before the body is buried so that the deceased can leave this world unbound and have no problems moving about the other world. For the same reason, all the knots in the deceased's clothing are undone and removed. There is evidence that the ropes or cords used to tie the limbs of the deceased during rigor mortis are items eagerly sought by witches and sorcerers. Some attested uses include the following: In Western Podillia, for example, the cords taken off the deceased's hands are sewn into the sleeves of a man's shirt to prevent him from beating his wife. In the same region, ropes used to tie the legs of the deceased are used to tie the legs of a cow. This is supposed to prevent it from kicking while it was being milked. All across Ukraine, items taken off the bodies are used in folk medicine for magical healing rituals, such as curing headaches and alleviating muscle and back pain.

The body of the deceased is covered up to the chin by a linen sheet, a woman's headdress (namitka) or, occasionally, an altar cloth. In the Carpathian Mountains a wedding rantukh can be used. This is the white sheet-like piece of a woman's wedding outfit, which covered her head and was draped around her face and over her neck and shoulder. Another traditional covering is a white plakhta, the rectangular piece of woven fabric, which is wrapped around the waist and serves as a skirt. A paper wreath (vinchyk) with an inscribed prayer (prokhidna) is placed on the deceased's forehead, and a small icon wrapped in an embroidered towel on his or 
her chest. A burning candle stands at the head of the deceased and an icon-lamp hanging under the icons in the corner is lit. On the table, people traditionally set a burning candle inserted in a grain or flour-filled bowl. It is also obligatory to set out bread, honey and a special funerary dish called kolyvo on the Right Bank of Ukraine, to the east of the Dneiper River, and kanun on the Left Bank, to the West. In the Carpathians, the special funerary dish is called pshenytsia or kitia.

While the body is being prepared for laying out, one of the deceased's relatives is supposed to invite two or three local artisans to make a coffin (domovyna, derevyshche, dubovyna), a coffin lid (viko), and a cross for the grave. All three items are made of oak or pine. Old people often purchase the requisite wood in advance and store it, as they do with their funeral clothes. To protect themselves from death, the coffin-makers (trunachi) begin their work with an incantation. "In order to stop evil from entering" fifteen crosses are engraved on the completed coffin, three on the bottom and three on each side. Chips and shavings produced in the process of making the coffin cannot be burned in the stove. To do so would make "the house turn cold" like death. Instead, some shavings are spread in the coffin as a kind of mattress and the rest are burned beyond the boundaries of the property where the coffin makers worked and the ashes are either buried in the ground or strewn into running water. The coffin and the cross are commonly made for free, but it was customary to feed the workers and treat them to some horilka during their work breaks.

The deceased is usually left in the house for two nights before being buried. During this time, the doors in the house and all ancillary buildings are kept open. This is supposed to help shorten the time the soul must spend in this world redeeming itself. It is also supposed to allow "the dead person to take all that he needs," "so that he does not have to return." During this period also, no work can be done in the house or out in the field. If a member of the deceased's household works while the body lies in the house his hands "will become weak and will continue to go numb repeatedly for one year." In addition, avoiding work in the presence of the corpse is supposed to assure peace for the soul of the deceased and comfort for his body.

Everything living and fertile has to be protected from the touch of death. To that end, all seeds are removed from the house. Containers holding grain are regularly opened and the grain stirred. If there is standing grain, in other words, if fields of oats, or wheat, or rye have already started to form ears, these plants have to be touched at least briefly so that all of the plants move. The same is done to potato plants and to garden vegetables. There is a prohibition on speaking about the dead near a laying hen because it is believed that this will make her eggs infertile and keep them from hatching.

Concern for the living is expressed through the custom of covering all mirrors. It is said that glancing into a mirror right after looking at the body of the deceased will cause jaundice. The same belief accounts for the prohibition against children playing with mirrors at any time. Those who are about to pay their last respects to the dead are supposed to avoid looking into a mirror or else "a young person in the family will die." According to another explanation, mirrors are dangerous because the glitter of the mirror's surface intensifies the suffering of the dying and so all mirrors must be covered during the last minutes of life. It is also thought that the mirror itself will be affected (become murky or grow pale) if it is not turned toward the wall when someone dies. 
During the ceremonial dressing of the corpse, close female relatives commence their crying and their lamentations for the deceased. Laments have a formal and traditional character and are considered obligatory at certain ritual points after death. These points are the visitation of friends and relatives and their viewing of the body, the carrying the coffin into the house, the transfer of the corpse from its bed to the coffin, the removal of the body from the house, and the lowering the coffin into the grave. While laments are characteristic of most of Ukraine, some areas have different customs. Carpathian Lemkos, for example, accompany their funerals with quiet tears. In Sub-Carpathian Ukraine it is believed that tears extinguish the fires of hell, and thus there are accounts of hiring weepers, at least in the past, to make sure that there would be plenty of tears at a funeral [Hnat'iuk 1912: 207-08].

There are other components to the mourning ritual. Girls mourning their parents, for example, do not braid their hair until after the funeral. Leaving hair loose is supposed to "keep the path to the other world straight." Men from the deceased's household do not shave or comb their hair for two weeks after the death and do not wear hats until after the funeral. In fact, all men are supposed to remove their hats in the presence of the body. Widows cannot marry sooner than six months after their husband's death and parents mourn their children for a minimum of six weeks. Finally, for a full year after the death, members of the deceased's family are supposed to dress plainly. For that same period of time, no weddings can be held in the home, and children are not allowed to play merry games, dance, or attend parties in the homes of others.

\section{Funeral And Burial Rites}

The rituals and customs that constituted the funeral itself reflect beliefs in the afterlife and in the persistence of a special, intense communication bond between the living and the dead. Parting rituals are a central element in funeral rites. They take place in the home, in the yard, on the streets of the village, and in the cemetery. Parting rituals are bi-directional in nature. All are performing by the living, but some rites are performed by the living on their own behalf, while others are performed on behalf of the deceased.

Parting rituals begin before the actual funeral and internment. The first such ritual is a very important one. It is the practice of "visiting" with the dead and sitting near the corpse for a certain period of time. Someone is supposed to attend to the corpse both during the day and at night and leaving the corpse alone is considered a sin. It is also said that the body has to be "guarded" to prevent its being overtaken by evil spirits. For example, it is believed that if a cat jumps over the body, the deceased will turn into a vampire. Relatives in general and household members in particular are expected to be present near the body continuously. In addition to the relatives, a few elderly women (at least two or three), who are themselves nearing death and make a practice of regularly attending the funerals in their village, are also "on duty."

Those who come to pay their last respects are to look at the icon, cross themselves, and say "The Lord's Prayer" on behalf of the deceased, all while remaining on the threshold. Only after performing these ritual acts can they enter the home and look upon the body. After approaching the body, visitors are supposed to light a candle for the deceased. Formulaic expressions are used to console the grieving family and visitors say something like "may he rest in God" and "may God forgive (forget) his sins." The visitor is expected to sit near 
the body for some time. Then, upon exiting, the visitor is supposed to pause at the door and, while standing in the doorway, make the sign of the cross in the direction of the deceased and say his goodbyes to those remaining.

Unlike other visitors, close relatives and neighbors, are expected not just to visit, but to help. One way they do so is by bringing provisions for the funeral. Those close to the deceased and his or her family might bring bread, grain or flour, eggs, honey or sugar, money and so on. Most of the food is consumed right after burial as part of the meal that constitutes the wake. Some of the food goes to other uses such as gift-giving. Food gifts are distributed by the family of the deceased to their fellow villagers so that they will remember the departed person and think kindly of him. The tradition of parting gifts is especially well developed in RightBank Ukraine. Some food items, especially so called hostyntsi (treats) such as cookies, candy and nuts, are later given out at the cemetery and at the post-internment supper in remembrance of the soul. They also become part of the memorial gifts known in Left-Bank Ukraine as panykhyda and, in Right-Bank Ukraine, as myska, sluzhba, and parastas. In the Zhytomyr and Kyiv regions, myska refers to a plate with three buns bound together and a candle inserted in the middle, supported by a small amount of grain. The myska can also contain some candies and a few apples and nuts. In the Carpathian part of the Dniester Lowland, parastas is composed of kutia, meaning a porridge of whole wheat, berries, some bread and honey, a cross and candle. These dishes are of a ritual and sacrificial nature; they are not intended as delicacies. A prayer of thanks is said over them on the day of the burial, and they are given to the priest and other church officials on behalf of the deceased.

Spending the night near the body is an important part of the visitation ritual. This custom is variably called ity nochuvaty (to go for a sleep-over), vecheria (supper), and sydity nad kolyvom (nad tilom) (to sit by the kolyvo or by the body). In the western areas of Ukraine the terms used are posyzhyny, pryvid, svichennia, among others. According to folk belief, one's nighttime vigil will be reciprocated after one's own death. Thus nightfall brings the greatest number of visitors to the home of the deceased. The room is continuously lit by a taper or a small oil lamp (kahanec'); alternatively a church lamp (svitylo, stavnyk) or icon lamp can be rented from the church. The deacon reads the Psalter for the expiation of sins and sings death-hymns (psalmy). Often, only women-singers (pevchi, spivushky) are invited. The nighttime visitors hold quiet conversations, reminisce about the life and virtues of the deceased, or talk about their own daily routine. From time to time they cross themselves and pray. At midnight the family invites their guests to a meal consisting of hors d'oeuvres, wine, horilka, and other small treats.

In South-western Ukraine, the night gatherings have certain features peculiar to that region alone. Thus, in the Dniester Lowland, young people are allowed to have fun and play games after supper, especially if the deceased is a young man or woman. The names of the most popular games, such as Lubok, Hrushka and Lopatky are applied to the nighttime visitation itself. This tradition is most developed in the Carpathians. Here "the games by the dead" are accompanied by raucous, loud behavior, which has some of the elements of a mock-fight and is erotically charged. According to folk interpretation, Lubok-style gatherings are supposed to alleviate the family's sorrow (shchob domashnim zhuru umenshyty) [Hnat'iuk 1912: 311]. Nevertheless, the roots of the funeral games, which persisted in the Carpathian regions of Ukraine in modified form until the mid- 
1900 s, reach as far back as pagan funeral banquets, where ritual laughter and ritual jousting in honor of the deceased are attested.

The funeral ceremony and burial usually take place on the third day after death and have to be done in the morning, with the wake coinciding with the mid-day meal. It is during this time that laments reach their peak, making the psychologically difficult final farewell to the deceased especially emotional. A religious ceremony, usually conducted by a priest, always accompanies the many folk rituals. It is considered prestigious to have a church official participate in all stages of the funeral, the ones that take place in the home, the yard, during the funeral procession, in the church, and at the cemetery. However, this entails a considerable expense and only the well-to-do can afford to hire a clergyman for all of the funeral stages. In the majority of funerals, a priest is present only at the service in the home and at the cemetery and sometimes he officiates at just the latter. It was considered highly desirable to bring the body into the church and to conduct one of the services there, but the feasibility of so doing depends to a large extent on the location of the church.

On the day of the funeral, often before the arrival of the priest, the coffin is brought into the house and prepared to receive the body. The bottom of the coffin is filled with the shavings left over from the construction of the coffin, covered by a blanket. Wood shavings and some hay serve as the pillow. The clothes worn by the deceased at the time of death can also be put inside the coffin, along with any items believed to be needed by the dead in the world beyond. The exact nature of these depends on the deceased's age and his or her occupation and tastes. Thus, money is always placed in the coffin so that the deceased can "buy himself a place" in the other world or pay "to redeem his sins." More person-specific items might include a walking cane for old folks so that they could get around more easily. Men always "receive" a hat and are given tobacco, a smoking pipe (kuryvo, liul'ka z kalytkoiu) or a bottle of horilka. For women, tools associated with the fiber arts are commonly placed in the coffin. Thus, weaving implements, drop spindles, a distaff (kuzhil), a needle and thread, some wool or a plaited straw band (pereveslo) are items routinely placed in a woman's coffin. To deceased children people give a small wax bowl "to eat from," an egg, an apple, and a braided bread (kalach). It is common to give the deceased some extra clothing "as a spare" or so that he can "change his clothing" in the afterlife. The custom of placing a change of clothing in the coffin is still practiced in Right-Bank Polissia.

The final arrangements made for the deceased reflect the belief that the dead will meet and communicate with each other in the other world. It is believed, for example, that children will find the midwife who had delivered them and pester her. A well-known Ukrainian custom, designed to protect a woman who has served as a midwife, is to place a small bag with poppy seeds in her coffin so that she can "give these out as ransom to her "grandchildren" in the world beyond." In the coffin of a parent, who has survived one of his or her children people place five braided breads and some money. These are designated as "treats for the children."(4) It is common to use the deceased as messengers and the practice of sending greetings and request for forgiveness to those who died earlier through someone who is about to be interned is very widespread. Items can be sent to the other world also. For example, if a person dreams about a relative who died a while ago and that relative reproaches him, complaining that he does not have the extra clothes, or the cane, or candle that he needs in the 
afterlife, the dreamer can "send" the requested items through the newly deceased by placing them in his or her coffin.

The funeral proper begins with the arrival of the priest who conducts a service (in folk terminology: "pravyv pokhoron, panykhydu, oprovid"). The consecration and blessing of the previously mentioned memorial gift plates is part of the ritual. In the Carpathians, where a large number of such plates are assembled from a variety of foods with a lit candle in each plate, this is called pravyty parastas (to celebrate a parastas) and resembles a religious rite in honor of the deceased and ancestors. Special terms exist for the other components of the service as well. For example, kazannie refers to the part of the priest's speech where he lists the deceased's virtues whereas proshcha signifies the priest's request for the deceased's sins to be forgiven by those present at the service. The priest uses incense to scent the coffin and then sprinkles it with holy water. When the service is over, the body is lifted using the two towels and placed inside the coffin, which is then taken out of the house.

Carrying the coffin with the body out of the house is a central part of the funeral. As such, it is characterized by a large number of ritual acts with a variety of functions. Prior to the actual removal of the coffin there are acts that symbolized a union of the living around their dead family member. Through these, they collectively say farewell as their relative leaves his home and native land for the last time. The form that this ritual takes in the Chernihiv and Sumy regions is for the relatives of the deceased to stand in a circle around the coffin after the memorial service. As they do so, they light and exchange nine or twelve candles (providnychok) "so that we can meet in the other world."(5) A variant of this ritual practiced in Pokuttia has the family carry lit candles and circle the deceased three times, all the while saying prayers (prypovidaly). Afterwards they stop to kiss the deceased.

In many ethnographic zones of Ukraine, excluding Polissia, it is traditional to lower the coffin to the doorstep and to knock it against the door jam three times [Havryl'iuk 1985: 35]. This allows the deceased to say goodbye to his or her home (rozproshchuiet'sia) and it is believed that, having bid the house farewell, the dead person has no reason to return again (vidkloniuiet'sia, shchob bil'she ne vertatysia). It is also said that the dead can hear everything that is going on in the house until the coffin is knocked against the doorstep [Hnat'iuk 1912: 206].

Certain of the rules of behavior practiced at the time that the body is carried out have a protective function and are supposed to guard the well-being of the deceased's family's and to protect the life and health of the living. They counteract death as personified by the deceased and alleviate the natural dread of mortality. Among the rules intended "to drive away death" are the dictate that the body always has to be carried out feet first and never by the family closest to the deceased. To protect himself, each pallbearer is supposed to carry a metal object in his pocket. Finally, rye and wheat are thrown at the coffin and at the people carrying it just as they leave the house (na vykhid).

Once the coffin is out in the yard, the house door is promptly closed and the place where the body had just lain (the table or bench) is strewn with whole grain. To protect the family's well-being, oats are thrown under the threshold. Many other protective and preventative measures are employed. These include: turning the table upside-down, turning over the bread trough and not using it for a week, sprinkling holy water or placing 
some bread or an axe on the "death" bench, the one on which the deceased had laid in state, and driving a nail in the underside of this same bench. There are also more complex rites. In Bukovyna and Hutsulshchyna, for example, after the coffin has been carried out, the family sits on a bench and everyone holds on to the same kalach so as "to have no more death in the house." Alternatively, they take turns holding a kalach in their laps while looking through the window at the coffin "so that the deceased will not return to us in our dreams" (shchob ne vvyzhavsia).

After the coffin with the body has been carried out of the house, it is either taken immediately to the cemetery or left standing on a bier in the yard, watched over by two or three men. At this point everyone else goes back inside the house for a funeral supper. Such a sequence of events is characteristic of some areas of Right-Bank Polissia and the Carpathians. According to a more widespread tradition, the ritual mourning continues in the yard. At the request of the family, the Gospel is read and funeral hymns are sung. Hutsuls often conduct a parastas. It is here that those who cannot follow the funeral procession to the cemetery say goodbye to the deceased. Some examples of people who are forbidden from participating in the funeral procession are pregnant or menstruating women. It is widely held that the mother should not go to the cemetery for the burial of her first child. If people want to ask the deceased to pass along greetings to those who had died earlier, it is appropriate to make this request while the coffin stands in the yard. It is also in the yard that people put bread in the coffin (shchos' iz khlibnoho) so that it can be "sent" to those who had passed away previously. Farewells spoken in the yard typically include a ritualistic dialogue about the forgiveness of sins. If a priest is not present to call for forgiveness, a family member can speak on behalf of the deceased and address all those present.

Funerary objects are typically arranged in the yard. The cross that is going to be set on the grave of the deceased is tied with a rushnyk. A rushnyk called the "pokryvets" is placed on the lid of the coffin and a bread is placed on top of that. A rushnyk or kerchief is tied around one of the arms of each pallbearer. In the Dniester Lowland and the Carpathians, a rushnyk is strung through a kalach and tied to each of the four handles of the bier, in this area called a nosha. If the funeral is for a child or youth, then a cherry or fir tree is strung with colored ribbons, used as a decoration during the funeral, and later planted on the grave.

Someone in the procession takes it upon himself to carry ritual food as well as sacrificial and memorial gifts to the cemetery. These are given out in commemoration of the deceased (na spomyn dushi, or among the Hutsuls, na prostybih). In Bukovyna, these gifts are called pomany and are especially numerous. They always include a kalach and candle, as well as a household item, such as rushnyk, kerchief, rug (nalavnyk or lizhnyk) and sometimes even a chicken or a sheep. Different pomany, generous or modest, are prepared with the specific recipient in mind. Thus, the gifts for the clergyman or the sexton will be more generous than those for the churchwarden or the people who dress the body and dig the grave, and so on. As the coffin is carried out of the yard, three handfuls of freshly-cut grass (pashnia) are thrown after it and, once the coffin is outside the gates, the gates themselves and the doors of the cattle-shed, stable, and pig pen are promptly closed. In the Dnieper Lowland and Podillia, a red ribbon or belt is tied to the gate as a magical protective talisman [Kuzelia 1912: 153.] (6) 
The coffin is transported to the cemetery (called tsvyntar, mohylky, hrobovyshche or, by the Hutsuls, temety) in one of a number of ways. It can be carried on the pallbearers' shoulders or on a special bier (noshi, mary). The coffin can ride on a horse or ox-drawn cart or sled. The coffin of a small child is usually carried on rushnyky by young people of the same sex as the deceased. The coffin can be transported with its lid (viko) either open or closed, depending on the local tradition and other circumstances.

The funeral procession is led by the person carrying the cross, followed by people carrying the church banners (khoruhvy). Then comes the coffin itself. If the coffin is open, it is customary for the coffin lid bearers to precede the coffin. After the coffin walk the members of the deceased's family and then the rest of the villagers. If the priest takes part in the procession, either walks in the procession or he rides on a horse in front of the coffin. The funeral processions of the Hutsuls are traditionally accompanied by two or three trembita players, who walk approximately 100 meters ahead of everyone else.

The procession stops at all road crossings, which in folk belief and ritual represent loci with special magical and sacral potency. In some localities in Polissia and the Carpathians, twelve stops are required, including before a crucifix (fihura), at a bridge, at a well that is located at the crossroads, and at a bend in the road. When the funeral procession comes to a halt at one of these stopping places, the people in the procession cross themselves, family members weep, and someone says a short prayer. In Bukovyna it is believed that the coffin also has to be carried over a kerchief with a pomana, which has just been laid on the ground. The pomana bundle is then immediately given as a gift to someone in the procession. If a bridge is crossed, the pomana is placed on a rushnyk, which symbolizes the last trip of the departed and reflects the belief that this trip includes a ferry crossing into the other world. In Chernihiv region, the funeral path is customarily strewn with periwinkle, "so that the soul can find its way and fly back home."(7)

Those witnessing a passing funeral procession exercise caution: they close and lock the gates of their properties. They close and lock the doors to their homes. If anyone in the house is asleep, that person needs to be awakened. If an infant is asleep in the house, a knife is placed under him or her. People scrupulously avoid looking at the body through the window for fear of illness. Crossing the road in front of a funeral procession is similarly avoided, as it is believed to cause mertva kistka (bone deterioration).

The procession always stops in front of the church. The coffin is carried inside, if at all possible, and the priest says the departure prayer (prokhidna molytva). Provided the family has arranged it and is able to pay, a mass (Obidnia) is also conducted. Once at the cemetery, the open coffin is placed near the grave. The grave has to be freshly dug, for it is said that the grave should not remain open overnight (iama ne povynna nochuvaty). The priest recites the Office for the Dead (panakhyda or litia) and blesses the grave. The family weeps, laments for the last time, and kisses the deceased goodbye. The grave-diggers nail the lid shut and the coffin is lowered into the grave on special ropes or belts called patel'ky, ochkury, shnury, vazhky or pasy. In Polissia, it is customary to use rushnyky and to leave them in the grave, burying them along with the deceased. Finally, the priest "seals" the grave by using the shovel to draw a cross in the soil at each of its corners. He then throws the first handful of earth into the grave, on top of the coffin. Everyone then throws three handfuls of dirt into the grave saying "may the soil be like down [for you]" (shchob zemlia bula pukhom), and "may you rest easily in 
the earth and may the earth keep you" (shchob lehko lezhav i zemliu trymav). The ritual of throwing handfuls of soil is not performed by everyone. Only cousins and more distant family members are supposed to participate in this ritual. It is considered a symbol of parting "for (it allows) the dead to know who has come to the funeral and who has not." Throwing dirt on the coffin is also viewed as a protective measure: "so that the dead wouldn't come to us in our dreams." The dead here are understood to mean both the person who has just died and those who had passed away earlier.

In folk belief, the dead are seen as ancestors who do not sever their ties with their family and are able to either help them or punish them as they deserve. Living descendents can be punished by the dead for failing to honor and preserve their memory, for example. Because of the close and continuing relationship that families maintained with their ancestors, rituals of caring for the deceased do not end at internment. The latter is but one step in the funeral process, leading to the rituals of the wake, performed immediately after burial, and to commemorative meals held on certain days of the calendar year.

\section{The Customs And Rituals Of Wake And Commemoration}

Legends and beliefs about the fate of the dead play an important role in the system of post-burial customs. According to these legends, the soul of the dead may appear as a bird or a flying insect such as butterfly, bee, fly, or beetle. It may take the shape of a spider or manifest itself as the shadow of a human being. It may also announce its presence with certain sounds, such as a knocking or rustling noise. The soul is believed to return to the house on the ninth, twelfth and fortieth day after death. Common expressions of this belief are to state that "the soul is in the house," "it flies back for a drink of water," "it comes back for dinner." The soul's favorite resting place is purported to be in a corner on the stove, by the threshold, and in the icon corner (pokut'). To avoid harming the soul, the house is never painted or even swept on the days when it is believed to return. The soul is also supposed to come back to earth one year after the date of death. According to actual statements recorded from informants: "the soul stays in the house for forty days, then it flies around the property until one year has passed (since the date of death), then takes its leave, cries, and goes to its place." (8)

Beliefs about the presence of the soul on earth are reinforced by rituals honoring the deceased through commemoration and feasting. Immediately after death, namely right after the body is carried out of the house or right upon the return from the cemetery, people set out, "water for the soul," a glass of water which the deceased can use for drinking and for washing. In some areas, a rushnyk along with bread and salt are placed either on a windowsill, on the table or in the icon corner (pokut'). People check for changes in the water level and say: "what has evaporated is how much the soul has drunk." The water set out for the deceased is also viewed as a cleansing medium, something that the dead person can use to purify his soul, washing away his sins.

The events in the commemoration cycle occur in approximately this sequence: Immediately after burial, the family invites the priest and the villagers into their home for a funeral meal. Some of the terminology used for this meal includes: in Right-Bank Polissia, obid (dinner), pomynky (wake) or zhalobnyj obid (dinner of mourning); in the Carpathians, pomershoho hostyna (feast of the dead), parastas, horiachyna (hot meal), komashnia. 
Before sitting down to the meal, everyone who had just been to the cemetery performs certain purifying and protective actions. Everyone is supposed to wash his or her hands three times. This is done in a yard, before entering the house, and the water used for washing is supposed to run down onto the shovel used to dig the grave. Once inside the house, each person is supposed to touch the chimney or glance into the stove. These actions help the living "to forget about the dead" (shchob zabutysia mertvoho), "lest [the dead] appear in a dream" (shchob ne maryvsia). Occasionally small coins are thrown from the doorstep towards the stove. The coins are regarded as a token of purification and sacrifice.

The dinner begins with the guests crossing themselves, saying "The Lord's Prayer." They then have to each eat three spoonfuls of kolyvo (also called kanun), a dish of wheat, honey and raisins specially prepared for the wake and blessed in the church after the funeral Mass. Next, the guests drink horilka or wine and eat borshch (red-beet soup) or kapusniak (cabbage soup), which has to be steaming hot (z paroiu). The idea that steam has to be rising from all dishes served at the wake comes from the belief that the soul of the dead attends the dinner and feeds on the steam. A common saying in the Dnieper Lowland goes as follows: "the steam [is] for you, the meal [is] for me; where the soul goes, there the steam follows." The rest of the meal depends on the local traditions and current fasting requirements, if any. It can include pastries, porridge, varenyky, kholodets' (meat in aspic), cabbage rolls and fried fish, among other dishes. The last dish is always compote or a fruit pudding (uzvar or kysil'). After the dinner, each guest receives a gift of either a small kalach with a candle or filled pastries (pyrizhky), scones (korzhyky), honey-cakes (prianyky) or some other treat. Guests thank their hosts for the dinner and wish them good health. For the deceased, they wish repose in the "heavenly kingdom" (tsarstvo nebesne).

On the night after the funeral, the adults do not sleep. Rather, they keep the candles lit and leave the supper on the table. In Right-Bank Ukraine, staying up all night after the funeral is called "seeing the soul off" (provodzhaty dushu). In the Cherkasy region, around midnight, a candle is lit in complete silence and placed on the table or in the icon corner. While this is being done, everyone should "look out for the arriving soul." The residents of this region firmly believe that the soul is "drawn to the hot candle" and flies toward it, but it can only be seen by the righteous and those with the fewest sins. Some legends tell of all deceased family members coming home during this nighttime vigil. They speak of small, human-like shadows appearing at midnight and moving along the wall, from the stove to the icon corner. Others describe a procession of doll-like shadows (ide dekil'ka tinej-kukolok), the dead family, marching up the wall and disappearing in the icon corner. (9)

A commemorative dinner is customarily held on the ninth and fortieth days after death, as well as on the one-year anniversary. The dinner on the ninth day (dev'iatyny) is attended mainly by the close family. The other two meals are considered important, large-scale events, with everyone who had attended the funeral invited. For the family, major commemorative days begin with a trip to the church to deliver sacrificial gifts of remembrance and to request a memorial mass. Afterwards, the family visits the cemetery and holds the dinner itself, a meal similar in structure to the ritual dinner served immediately after internment. In addition to the above-mentioned dates, small wakes are occasionally organized for the immediate and extended family on the sixth, twelfth and twentieth days and six months after the date of death. 
Ritual feasts are not the only way to remember the deceased and to honor him. Other commemorative acts include having the family drink "water for the soul." Alternatively, water for the soul can be poured on the grave. Families often prepare individual commemorative gifts such as bread, clothes made out of the deceased's wardrobe, and give away objects that had been used during the funeral. It is common to leave a "supper for the soul" out in the house overnight and to take ritual food and drink to the cemetery and place it on the grave. At least one and usual some combination of these commemorative actions are performed either on the fixed remembrance dates, as stated above, or continuously throughout the period of forty days that follow death.

All of the memorial ceremonies listed above are tied to a specific dead individual. But the folk also attribute special importance to remembering dead relatives in general. Days for commemorating ancestors as a group coincide with certain dates and holidays of the calendar year and are dictated by the belief that the souls of the dead visit their families and former homes from time to time. Foremost among the ceremonies commemorating ancestors as a group are Provody (seeing-off), also known as Hrobky, Mohylky, Radul'nytsia, a holiday that takes place on the first Sunday after Easter. A priest is supposed to officiate at this commemorative event. In Right-Bank Polissia, Provody takes place on the first Thursday after Easter, also known as Mertvykh Velykden' (the Easter of the Dead) and Navs 'kyj Velykden' or Mavs 'kyj Velykden' (the Easter of the nymphs or mermaids). Prior to this day people visit the graves of their relatives, tidy them up and decorate them with new rushnyky and kerchiefs. On Provody itself, graves are covered with a table-cloth and food and drink, including Easter bread, painted eggs (krashanky, pysanky) are set out. The dead are greeted with the customary Easter greeting (Christ has risen!), and everyone eats, exchanges presents with neighbors and gives alms to the poor and elderly. When the family goes home, they leave behind a glass of water or horilka, a few eggs and some other food. An alternative to the family-arranged commemorative meal is a communal meal of remembrance. If a village holds such a meal at its cemetery, it is customary to install a few very long tables where everyone can sit.

The dead, especially those who died an unnatural death, are especially remembered on the Eve before Trinity Sunday, called zelena subota (green Saturday) or klechal'na subota. The latter term comes from the custom of adorning houses with green boughs (klechanniam) on that day. Four additional remembrance dates (pomynal'nytsi) are the Saturdays before the feasts of St. Demetrius, Sts. Cosmas and Damian, and St. Michael in the fall, and the first Saturday of Lent, in the spring. The old names for these dates, Didy (Grandfathers) and Rodychi (Relatives), typically used in the Kyiv and Chernihiv regions of Polissia, bear witness to the fact that these dates are associated with the commemoration of ancestors.

All of the remembrance holidays have a relatively stable and consistent structure. On the eve of the holiday the house is cleaned and everyone bathes and puts on fresh clothes. Afterwards, food is put on the table and left there. Traditional foods include borshch, porridge and kanun. Meat, however, is to be avoided. Once the food is set out, the living call their dead relatives by name and invite them to come to supper. Not only the food, but also spoons and other utensils are left out overnight so that they can be used by the dead. The next day is a holiday and no work is to be done in the house or in the field. Rather, commemorative gifts are to be taken 
to church for a memorial service. Another well known custom is to invite one's dead relatives for kutia on Christmas Eve.

Although this study is a preliminary one and focuses primarily on description, it shows that the funeral is an extremely important event in the life of the Ukrainian peasantry. Furthermore, there was and continues to be a strong belief in an on-going relationship between the living and the generations that have preceded them. Beliefs about the close ties between the living and the dead are reflected in both funerary practices and in commemorative rituals.

\section{NOTES}

1 The author's fieldwork data (AFD). Kyiv oblast', Tetiiv region, v. Koshiv. 1987. Notebook \#3, p. 7; Cherkasy oblast', Korsun'-Shevchenkivs'kyi region, v. Drabivka, p. 3.

2 AFD, Vinnytsia obladst', Koziatyn region, v. Shyroka Hreblia. 1989. \#3, p. 106.

3 AFD. Kirovohrad oblast', Oleksandriia region, v. Divoche Pole. 1990. \#3, p. 8

4 AFD, Chernivtsi oblast', Putyl' region, v. Dykhtynets'. 1981. \#5, p. 2.

$5 \quad$ AFD, Sumy oblast', Romny region, v. Perekopivka. 1985. \#10, p. 22

6 AFD, Khmel'nyts'k oblast', Krasyliv region, v. Antonino. 1986. \#4, p. 9.

$7 \quad$ AFD, Chernihiv oblast', Pryluki region, v. Okhyn'ky. 1987. \#15, p. 11.

8 AFD, Kyiv oblast', Tetiiv region, v. Koshiv. 1987. \#3, p. 19.

9 AFD, Cherkasy oblast', Korsun'-Shevchenkovs'kyj region, v. Drabivka. 1987. \#3, p. 10.

\section{BIBLIOGRAPHY}

Gracheva, G. N. 1983. Traditsionnoe mirovozzrenie okhotnikov Taimyra: na materialakh nganasan XIX-nachala XX v. [The Traditional Outlook of the Hunters of Taimyr]. Leningrad: Nauka.

Havryl'iuk, N. K. 1981. Kartografirovanie iavlenii dukhovnoi kul'tury (po materialam rodil'noi obriadnosti ukraintsev) [Mapping spiritual culture using Ukrainian birth customs]. Kiev: Naukov dumka.

Havryl'iuk, N. K. 1985a. “Karta-skhema: Areal'ni spivvidnoshennia stiiko povtoriuvanykh elementiv obriadovykh iavysch" [The schematic map: Correlations between repeated ritual phenomena and geographic area]. In the article: "Kyivs'ko-polis'kyi variant tradytsiinoi simeinoi obriadovosti na foni sumizhnykh terytorii" [The Kyiv-Polissia variant of traditional family rituals, as compared to neighboring territories]. In Zhelezniak I. (ed.), Kyivs'ke Polissia (etnolinhvistychne doslidzhennia) [Kievan Polissia (ethnolinguistic research)]. Kyiv: Naukova Dumka, pp. 24-40.

Havryl’iuk, N. K. 1985b. “Traditsionnaia pohrebal'naia obriadnost' Polesia v sravnenii s KarpatoBukovinskoi zonoi" [The traditional funeral rites of the Polissia region in comparison with CarpathianBukovynian zone]. In V. V. Ivanov (ed.), Balto-slav'ianskie etnokul'turnye i arkheologicheskie drevnosti. Pogrebal'nyi obriad. Tezisy dokladov [Balto-Slavic Ethno-cultural and Archeological Antiquity. Abstracts]. Moscow: Nauka, pp.28-30. 
Hnat'iuk, V. 1912. "Pokhoronni zvychai i obriady" [Funeral Customs and Rites]. Etnohrafichnyi Zbirnyk. Vols. 31-32, pp. 203-424.

Huziy, Roman 2002. Pokhoronni zvychai ta obriady ukraintsiv Karpat (19-20 st.) [Funeral Rites and Customs of the Ukrainian Population of the Carpathian Region (19th-20th centuries)]. Unpublished candidate dissertation, Lviv: Institut ukrainiznavstva im. I. Kryp'iakevycha.

Natsional'noi Akademii nauk.

Iaschurzhinskii, Kh. 1893. “Ostatky iazychestva v pogrebal'nykh obriadakh Malorossii” [Remains of Paganism in the Funeral Rites of Little Russia]. Etnograficheskoe obozrenie [Ethnographic Review]. Moscow, Vols. 11-13, pp. 93-95.

Ivanov, V. V., Nevskaia L. G. (eds) 1990. Issledovania v oblasti balto-slavianskoi dukhovnoi kul'tury. Pogrebal'nyi obriad. [Studies in the Field of Balto-Slavic Culture]. Moscow: Nauka.

Kravchenko, V. 1920. Zvychai v seli Zabriddi Zhytomyrs'koho povitu na Volyni. Etnohrafichni materialy [Rites in the Village Zabriddia Zhytomyr Region in the Volyn area]. Zhytomyr: Vydaie Volyns'ke naukove tovarystvo.

Kutel'makh K. 1994. "Pomynal'ni motyvy v kalendarnii obriadovosti polischukiv" [Funeral motifs in the calendar rituals of the people of Polissia]. In Stepan Pavliuk (ed.): Polissia Ukrainy: materialy istorykoetnohrafichnoho doslidzhennia [The Polissia of Ukraine: historico-ethnografic data]. Vyp. 1: Kyivs'ke Polissia [Kievan Polissia]. L'viv: Instytut narodoznavstva NAN, pp. 172-203.

Kuzelia, Zenon, 1912. "Ukrains'ki pokhoronni zvychai i obriady v etnohrafichnii literaturi. Ohliad studii i bibliohrafia" [Ukrainian Funeral Customs and Rites in Ethnographic Literature. A review of the scholarship and a bibliography]. Etnohrafichnyi Zbirnyk. Vols. 31-32, pp. 131-202. Republished as Pokhoronni zvychai ta obriady. Zibrav Volodymyr Hnatjuk [Funeral Customs and Rites]. Collected by Volodymyr Hnat'iuk]. Lviv.

Maierchyk M. 1996. "The Ornithomorphic Notions of the Soul (Genesis and Semiotics)." Thanatos. Studies of Integral Culture, L'viv: Instytut narodoznavstva, No. 1, pp. 92-105.

Shubravs'ka, M. M. and O. A. Pravdiuk (eds) 1970. Vesillia (u dvokh tomakh) [The wedding (in two volumes)]. Kiev: Naukova Dumka.

Shukhevych, V. 1902. "Hutsul'schyna". Materialy do ukrains'ko-rus'koi etnolohii [Materials on Ukrainian-Russian ethnology]. Lviv: Vydaie Naukove tovarystvo im. Shevchenka, Vol. 3.

Surkhasko, Iu. Iu. 1985. Semeinye obriady i verovaniia karel: konets XIX-nachalo XX v. [Family Rites and Beliefs of the Karelians: the end of the $19^{\text {th }}$-early $20^{\text {th }}$ centuries]. Leningrad: Nauka.

Worobec, Christine. "Death Ritual among Russian and Ukrainian Peasants: Linkages between the Living and the Dead." In Stephen P. Frank and Mark D. Steinberg (eds), Cultures in Flux: Lower-Class Values, Practices, and Resistance in Late Imperial Russia. Princeton: Princeton University Press, 1994, pp. 11-33.

Translated by Bohdana Badzio. Assistance with content and bibliography from Natalie Kononenko and Olena Boriak. 